Steen Nielsen \& Erland Hejn Nielsen

System Dynamic Modelling for a Balanced Scorecard: With a Special Emphasis on Skills, Customer Base, and WIP

Management Accounting Research Group 


\title{
System Dynamic Modelling for a Balanced Scorecard: With a Special Emphasis on Skills, Customer Base, and WIP
}

\author{
By \\ Steen Nielsen \\ (E-mail:sni@asb.dk) \\ $\&$ \\ Erland H. Nielsen \\ (E-mail:ehn@asb.dk)
}

\author{
Final Version: April 2006 \\ Addresses for correspondence: \\ Steen Nielsen, Department of Business Studies \\ Aarhus School of Business, \\ Fuglesangs Allé 4, \\ DK-8210 Aarhus, Denmark \\ Tel: +4589486688
}

The paper has been accepted and presented at the EAA Annual Congress, 22-25 March 2006, Dublin, Ireland. 


\title{
System Dynamic Modelling for a Balanced Scorecard: With a Special Emphasis on Skills, Customer Base, and WIP
}

\author{
By \\ Steen Nielsen* \\ Erland H. Nielsen ${ }^{\dagger}$
}

\begin{abstract}
Purpose - The purpose of this paper is to analyse some dynamic consequences of the theoretical foundations of the balanced scorecard (BSC) with the aid of a simulation approach based on part of a real BSC.

Design/methodology/approach - The model includes five perspectives and a number of financial and non-financial measures. All indicators are defined and related to a number of assumed cause-and-effect relationships. Time lags are included to stipulate one of the most important characteristic of BSC. We use the model to simulate different strategies or scenarios over time. Through three different scenarios we also demonstrate the effects of different variables on the profit or RoCE (Return on Capital Employed).
\end{abstract}

Findings - The results show that minimal changes in the three variables: skills, customer base and work in process may influence profit in different directions.

Research limitations/implications - Our analytical model is based on assumed associations hypothesized from literature as well as from our study of a case. In this type of model, the sensitivity of our results with respect to the assumptions should be analysed in subsequent studies. In addition, our model should be extended to cover a complete BSC of an actual company.

Practical implications - The model may be used as the first step in putting numbers on an integrated BSC model. The model is our first attempt to study an analytical version of BSC and to make inferences concerning optimal or rational relationships between different indicators and perspectives. The credibility or benefit of the model is insight into the finality of a model but it can also be used as a teaching exercise of BSC. It is easy to extend our model to more realistic circumstances, by including more measures or change time lags. Using the assumed cause-and-effect relationships between financial and non-financial performance measures, attention should also be paid to the definitions and the number of indicators.

Originality/value - A large number of case studies and surveys are now present in BSC literature. However, there is a lack of more theoretical and analytical modelling of the BSC. Our paper just throws a little light on this modelling approach.

Keywords: Balanced Scorecard, simulation, Vensim, model, analytical, time lag, indicators, financial measures, non-financial measures, loops, and steady-state-condition.

\section{Introduction'}

The aim of the holistic model of BSC is to implement and explain the strategy of the firm with subsequent translation into more operational terms (Drury, 2002; Garrison \& Noreen, 2000).

The emergence of information as a competitive factor has made many of the fundamental assumptions from the industrial age competition of traditional financial measures obsolete. It is no longer enough to gain sustainable competitive advantage just by rapidly deploying new technology

\footnotetext{
${ }^{*}$ Steen Nielsen is Ph.D. and associate professor at the Department for Business Studies in the Aarhus School of Business in Denmark, and member of Management Accounting Research Group.

${ }^{\dagger}$ Erland H. Nielsen is associate professor at the Department of Business Studies in the Aarhus School of Business in Denmark, and member of Logistic Research Group.
} 
into physical assets or by excellent management of financial assets. In the information age both manufacturing and service organizations need to develop new capabilities in order to become successful (Johnson \& Kaplan, 1987). In a global world economy companies must gain and retain loyal customers, introduce innovative products, mobilize employee skills, invest in technology, and implement new data bases and systems. Specific development measures only tell a fraction of a company's story. Therefore, the financial accounting model must expand to incorporate the valuation of the company's intangible and intellectual assets that satisfy customers and employees (Kaplan \& Atkinson, 1998). The balanced scorecard is developed to communicate the multiple, linked objectives that modern companies must achieve to be competitive. BSC translates mission and strategy into objectives and measures. BSC has also developed over time; from a performance measurement system (Kaplan \& Norton, 1992) into the so-called strategy map approach (Kaplan \& Norton, 2004) with focus on a generic business model based on causality between measures and perspectives; then into an interactive controlling system that drives learning and improvements (Simon, 1994); into a model that also encompasses intellectual capital, and finally into an integrated strategic planning process through the BSC (Horváth \& Ralf, 2004).

The generic model includes four different perspectives: the financial perspective, the customer perspective, the internal perspective, and the learning and growth perspective, as stated by Kaplan \& Norton $(1992,1996 b)$. The model enables you to control a number of key performance areas (or perspectives) based on a form of cause and effect logic. Subsequently, Kaplan and Norton (2001a,b,c) have developed an overall strategic management concept that consists of: i) transforming strategy to operational terms, ii) getting the company to focus on this strategy, iii) making strategy every person's job to achieve, iv) making strategy a continuous process, and $v$ ) mobilizing changes through a strong and effective management.

The foundation in BSC - in contrast to other holistic models - is the balance and the comprehensiveness and view into the future. In addition more recent versions of BSC focus on cause and effect logics through the concept of 'strategy maps' (Kaplan \& Norton, 2004). An example of a complete and integrated BSC is, however, still hard to find in the real world, although companies are trying to use BSC as described by Kaplan and Norton.

In conclusion, balance is needed between the horizontal and a vertical view, between financial and non-financial measures, between external and internal measures, between management control concepts such as costs and revenues, between short and long run and between hard and soft values. Balance also implies a balance between lead and lagging indicators (Kaplan \& Norton, 1996a, p. 56; 1996, p. 25).

The Balanced Scorecard developed by Kaplan and Norton (1992, 1996a,b, 1997, 2001a,b,c, and 2004) has become a very popular concept and an important innovation in almost all countries around the world. A large number of books, articles, and research papers have been published and discussed, examining the concept or part of it in theoretical writings (Maisel, 1992; Nørreklit 2000). One school appeared in the middle of the 90's and was dedicated to case-studies (Ax \& Bjørnenak, 2005; Malina \& Selto, 2001, Olve, et al., 1997; Kraus \& Lind, 2002/03). Another school began at the end of the 90's and beginning of 2000 and was related to a number of surveys (Hoque \& James, 2000; Töpfer et al. 2002) and in the Nordic countries (Bukh et al., 2000; Malmi et al., 2001; Nielsen Sørensen, 2004). Now a quantitative or model school is emerging, dedicated to analytically oriented studies and frameworks concerning the problem of transforming BSC into a dynamic model (Laitinen, 2004, 2005; Schöneborn, 2003).

How are these operational measures in BSC linked with the strategic objectives, and how can financial and non-financial measures be linked together? I.e. how can we translate the different perspectives and different kinds of measures into a common languish that can be used to evaluate and control the company? However, as it has been stressed repeatedly the core idea of a BSC is that 
the financial success of an enterprise can and should be measured or determined in the long run. Further, a short sighted view and maximization of financial results may also lead to a neglect of other measures and to a misuse of the financial element or to conflicting signals about the organization values (Kaplan \& Norton, 1996a). This will not create a long-term consensus for the stakeholders of the company.

The different perspectives should be connected to the financial and monetary success of the company. Therefore, the recognition of single elements or measures and their influence on other measures including the financial area is important for a success oriented company's control view. To bring strategies in action, measures have to be implemented that guarantee the achievement of the strategic goals and an increase in profitability in the long run. Linking measures to one single outcome measure has, however, been tried before, e.g., in the DuPont Powder Company, formed in 1903, where the financial outcome was on the Return of Investment (ROI). One problem is related to the high complexity of incorporating several measures to a single financial measure including different time delays. Therefore, the purpose of our paper is to start a discussion of this step and through a simple example to illustrate a structured dynamic model which integrates different time lag situations with the help of causal loop diagrams in a system-dynamic research. Even though our model may be labelled as a naive estimation of the real world, it has some credibility and does give some insight into the extreme difficulties to be expected in future work, when this analytical perspective is going to be explored. However, by using a dynamic model approach it becomes possible to conduct and test different scenarios by means of simulation.

There has been some discussion concerning the interpretation of the cause-and-effect relations. The important point is that the assumed relationship between different kinds of indicators can only be evaluated after some time. Besides, statistical tests and estimations have a long tradition in management accounting (see Kaplan, 1982; Hirsch, 2002). Kaplan \& Norton (1996a, p. 67) also point to this possibility by saying; 'managers can test the business theory's hypothesised causal chain of performance drivers and outcomes'.

The purpose of this paper is to:

1. develop an analytical dynamic model based on a theoretical foundation of BSC and on part of a real case with the aid of system dynamic simulations;

2. apply the model for different scenarios concerning a change in strategy combined with problems searching for steady-state-conditions.

Present literature only includes few discussions on the problem of converting BSC into an analytical model. Laitinen (2004) derives a theoretical foundation for BSC by using shadow prices and different strategies. Laitinen (2005) applies a microeconomic analysis of BSC on Nokia Corporation. The model includes demand, production, and objective mathematical functions. Strategy is described by the objective function to be maximized. However, an experimental simulation strategy has been mentioned by Brinberg \& McGrath (1988).

This has also been pointed out by Kaplan \& Norton (1996a, p. 67) who say: 'at this point, the Balanced Scorecard can be captured in a systems dynamics model that provides a comprehensive, quantified model of a business value creation process.'

The paper is organized as follows. In the next section we present a short introduction to financial and non-financial measures on the background of BSC. In section three, we introduce the concept of model in a classical sense and try to convert the specific assumption in a model of a BSC. In section four, we introduce our framework for our BSC model, its assumptions, containing elements of skills, customer base and work in process. In section five, we introduce three numerical simulation scenarios; one for the base situation, one for changing the number of trainings, and one 
for changing the order frequency. Finally, in section six we summarize the main results of the study and discuss the limitations and make suggestions for further research on the topic.

\section{Financial and non-financial measures}

Several economic theories discuss the choice of performance measures and indicate that performance measures and reward systems should incorporate measures that provide incremental information on managerial effort (Ittner \& Larcker, 1998). Many measures used in BSC have already been used and defined for decades in the literature for performance measures, both in Anglo-Saxon literature (e.g. Solomon, 1965), in German literature (Hahn, 1974) and in the Nordic literature, e.g. Johansson \& Östman (1995). Several of these may be called 'generic measures', e.g. market share; customer satisfaction; customer retention; profitability; EVA (Economic Value Added); because they are already accepted and have been used for decades.

Non-financial measures are normally considered short termed or operational measures, whereas financial measures are long termed and strategic measures, Anthony \& Govindarajan (2004). In BSC these two types of measures must work together. However, correlation between measures and perspectives also gives the opportunity for simulation, to search for optimization/minimization stages, to change substitutions between different input factors or to choose between different outcome measures.

There are two types of performance measures; performance drivers (also called lead indicators) and output measures (or lag indicators). Performance drivers also referred to as metrics are the ones that tend to be unique for a particular business unit and reflect the uniqueness of the business unit's strategy (Kaplan \& Norton, 1996a). If e.g. the company wants to reduce lead time in the internal perspective as part of its strategy, the company should choose the underlying lead indicators that support this part of the strategy, e.g., product design, speed of processing, DFM (Design for Manufacturability). Normally, BSC also clarifies the company's strategic goals and at the same time identifies critical drivers ensuring the strategy. As empirical work has shown, however, the learning process from BSC is a major factor. A maximum of 25 consistent and mutually reinforcing measures are normally said to be sufficient (Kaplan \& Atkinson, 1998).

\section{A-priori model considerations}

The most important objective for BSC is the feedback for learning and improvements for employees, the communication and information, and learning for executives (Kaplan \& Norton, 1996a, b, p. 15). The final goal is to be able to control the operational performance of the company, thereby securing the competitiveness of the company and increasing the value of the company in the long run.

Looking in classical literature for model building, e.g. in operation research accounting (Churchman et al, 1957; Hillier \& Lieberman, 1989; Sterman, 2000; Sterman et al., 1997) or in micro economics (e.g. Varian, 1997), accountants may find help to build and secure the validity of the BSC model (here validity as used by Brinberg \& McGrath (1988, p. 13), i.e. 'integrity, character, or quality to be assessed in relation to purposes and circumstances').

The assumptions above imply that the BSC model should provide aid to explore the consequences of alternative policies and environmental circumstance in such a setting (Sterman et al., 1997). Translating the thoughts of model builders such as Sterman (2000) and Churchman et al. (1957) into the BSC means that developers of BSC must consider the following components:

$>$ Problem Articulation/Boundary Selection: I.e. the general problem formulation of the BSC model, the definition of and the operational definition of strategy and vision. This also includes the number and choice of perspectives, the choice of 
including both performance-drivers (lead indicators) and output measures (lag indicators), and the feedback loops. It also includes the determination of key variables (depending and independent) and the definitions of each indicator. Finally, it includes the dynamic problem (known as the reference modes, which are literally a set of graphs and other descriptive data showing the development of the problem over time), i.e. what is the historical behaviour of the key concepts and variables.

$>$ Formulation of the Dynamic Elements: What are current theories of the problematic behaviour? All areas of BSC are covered by different theories (Chenhall, 2003). The endogenous focus implies the formulation of the dynamic hypothesis that explains the dynamics as endogenous consequences of the feedback structure (loops) using and developing maps of causal structure based on initial hypothesis, key variables, reference modes and other available data. Besides, strategy maps and other tools such as model boundary diagrams, subsystem diagrams, stock and flow maps (e.g. employees' knowledge vs. cost flows) could be used.

> Formulation of a Simulation Model: This process should be 'easy' when the above mentioned steps have been conducted. This step implies the specification of structure, decision rules, estimation of parameters, and the knowledge of behavioural relationships and setup of initial conditions. Kaplan \& Norton (2004, p. 366) also argue 'The collection of linked objectives, targets, initiatives, and budgets for a strategy theme, ..., provides a complete stand-alone business case for the piece of the strategy'. However, Kaplan \& Norton (2004) also use the term 'theme' as the building blocks of the strategy, meaning that each theme of the strategy should be considered as having 'its own microeconomic action plan'. Accumulating the microecnomic plans provides the macroeconomic model of the enterprise (Kaplan \& Norton, 2004, p. 369).

$>$ Testing: I.e. comparing with the reference modes above and asking 'does the model reproduce the problem behaviour adequately for the intended purpose'? Does the model behave realistically when stressed by extreme conditions? How does the model behave given uncertainty in parameters, initial conditions, model boundary, and aggregation? This has also been pointed out by Kaplan \& Norton (1996, p. 258) in what they call 'management game simulation', or 'without quantifying, a strategy objective is simply a passive statement of intent' (Kaplan \& Norton, 2004, p. 365).

Modelling is inherently creative, because individual modellers have different styles and approaches (Sterman, 2000, p. 87). It is important to be aware of the structure of BSC model and how the model behaves (exponential growth, goal seeking, oscillations, steady-state-solution etc.). These behavioural characteristics depend on feedback loops, stocks and flows, linearity and nonlinearities created by the interaction of the physical and institutional structure present in the model. Besides, traditional concepts such as cost vs. spending, capacity utilization etc. have to be determined (Cooper \& Kaplan, 1999).

In order to make the BSC an apt model for predicting future financial results, the time lag or time delay problem must be considered. The time delay will be present both between performance measures and between perspectives. The time delay is defined as a process whose output lags behind its input in some fashion (Sterman, 2000, p. 411). There might be material delay and information delay. Both types assume that there is at least one stock within every delay. In some cases the time delay will be short, but in other cases there will be longer time periods, e.g. customer 
satisfaction and customer profitability or between a customer outcome and company net profit. The dynamic assumption and the feedback loops imply that it will be possible to reach a steady-statesolution before an evaluation of the model can be conducted.

Finally, the manual of the model should include plan of actions in case of e.g. bottleneck problems or in case research and development cannot make the suggested improvements. In the BSC, terms like strategy, mission and vision are used. The mission provides the starting point. It defines why the organization exits or how a business unit fits within a broader corporate architecture (Kaplan \& Norton, 2001c, p. 72).

The vision is a short and inspired syntax sentence that all members of the company should understand. E.g.: 'we want to be the most successful company within our field' or 'we want to satisfy customers and make profitability above average' or as mentioned at Rockwater (see Kaplan \& Norton 1993,p 135) 'as our customers' preferred provider, we shall be the industry leader'.

Although the definition of strategy differs, there is a general agreement that a strategy describes the general direction in which a company plans to move to attain its goal (Anthony \& Govindarajan, 2004, p. 54). Strategy is defined as a set of hypotheses about cause and effect and expressed in a sequence of if-then statements (Kaplan \& Norton, 1996b) in relation to what the company wants to compete on to reach its mission and vision. E.g. if the company wants to improve its profits by improving the knowledge of the sales staff, this may take the following sequences: if we improve employee education, then the employees gain more knowledge of the products, and if the employees have more knowledge about the products, then they are able to target a better sales campaign, and if they can make a better sales campaign, then they are able to improve the profitability of the company. Kaplan \& Norton (1996a, b) use and describe different strategies or themes that could be used. E.g. in the financial perspective a revenue growth and mix, improvement and asset utilization could be combined to the classical build, hold, harvest, and divest developed by Boston Consulting Group or Porters' (1985) Relative Differentiation Position matrix. Each of these generic strategies demands different financial and non-financial measures in BSC.

One of the most important aspects of a BSC model is to be able to make feedback for learning and improvement, e.g. increase yield, reduce defects, improve cycle time or throughput, or reduce resource consumption (Cooper \& Kaplan, 1999).

\section{Figure 1}

\section{Relations between mission, vision and strategy}

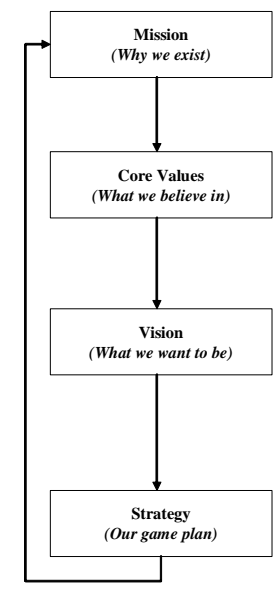




\section{Inspired by: Kaplan \& Norton (2004, p. 33).}

The company may use either historical data or ex-ante oriented data or a combination. Historical data generated from the company's MAS (Management Accounting System) can be used to make statistic tests or to find an appropriate probability distribution that matches the distribution of the data. Some relations may be weak while others are strong; some are based on belief while others are based on actual statistical tests. Software systems like SAP/R3, Oracle, Axapta, and Peoplesoft normally have a facility for extracting data to be used in separate statistical packages like Excel, SAS, or SPSS. In both cases the BSC model should be evaluated on its ability to be able to make prediction and improvements.

\section{The 'case company'}

In our generic System Dynamics model presented in this paper we have used only part of the case company's balanced scorecard. Our model is centred on three basic state variables:

Skills

\section{Customer Base}

\section{Work in Process}

It is a generic setup that in part is used by numerous authors (e.g. Sterman 1997; Schöneborn, 2003), and as a consequence of obeying to the System Dynamics model building logic and laws the model structure is almost given in a unique fashion.

The dynamic behaviour of the proposed model is partly determined by the integration process (implicit delays) on these three state variables as well as the various assumptions explicitly defining behavioural reaction and the delays put down in smooth as well as explicit delay-functions.

The BSC structure that has been reasoned upon in the previous part of this paper is shown in figure 2 below.

Figure 2

\section{BSC model structure}

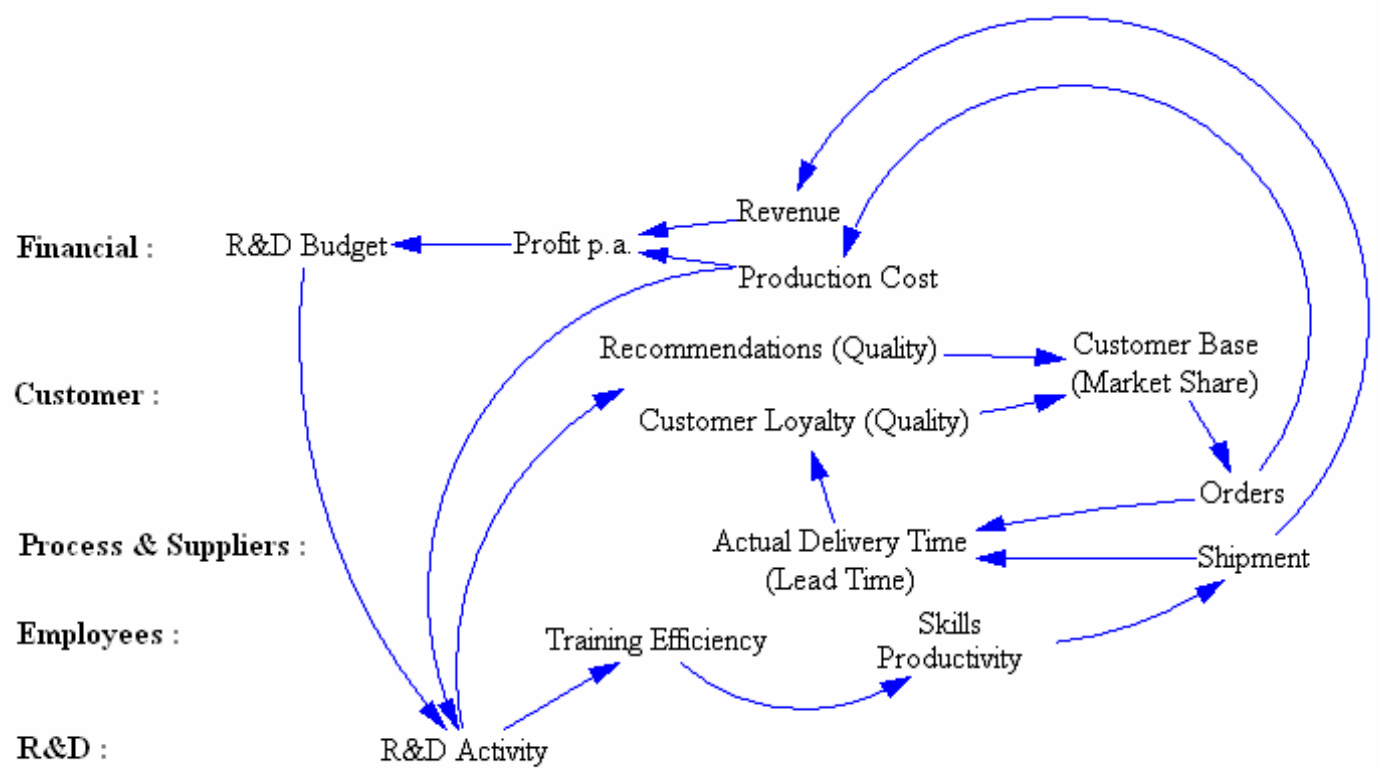


Translated into System Dynamics terms combined with the choice of state variables "Skills", "Customer Base" and "Orders in Process" a corresponding generic structure might look like the one depicted in figure 3 below.

Figure 3

\section{The documentation of the dynamic model}

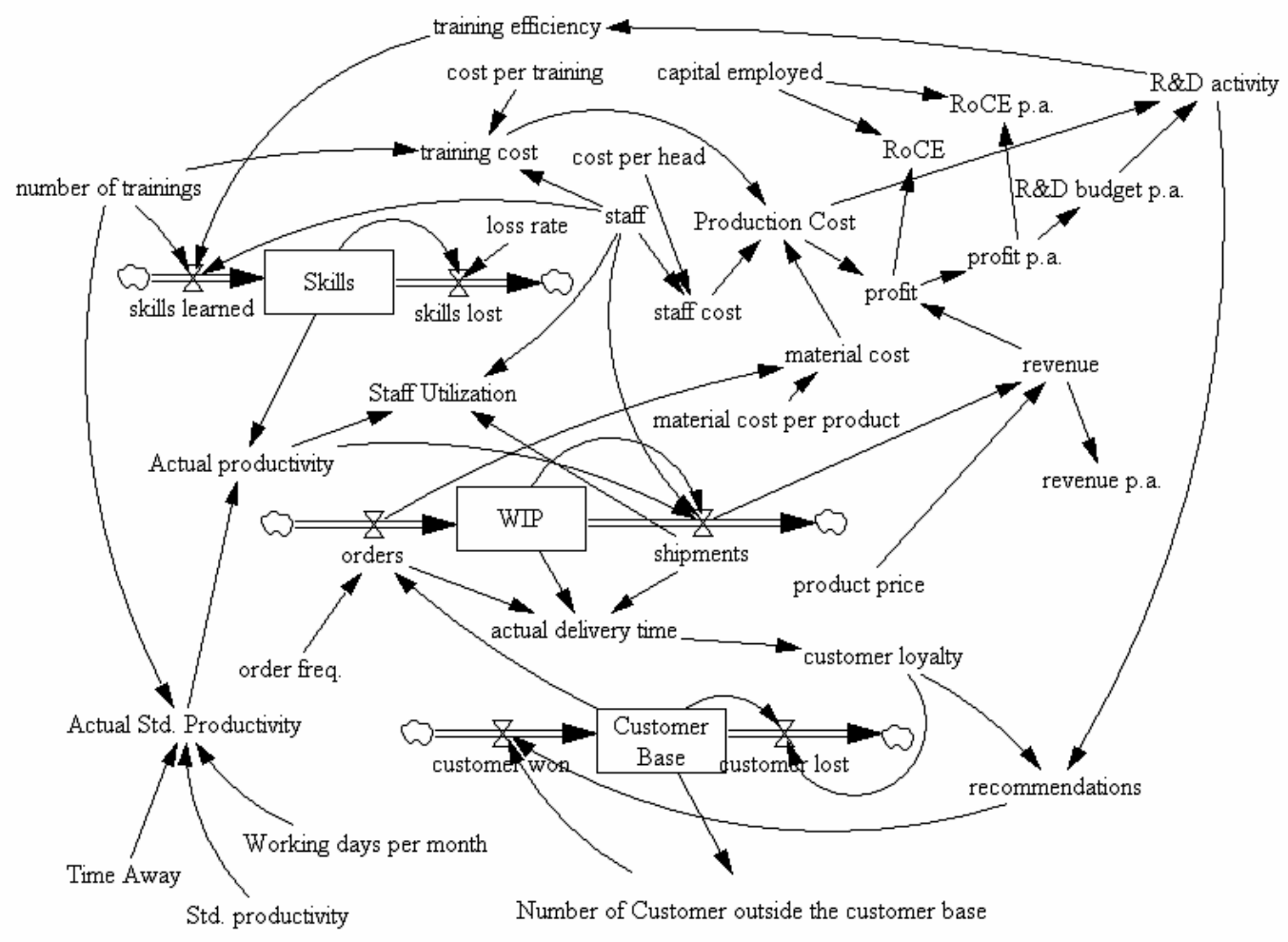

The dynamics for the three state variables are given by their respective rate-inflow and rate-outflow functions as listed below.

Dynamics of the state variable "Skills":

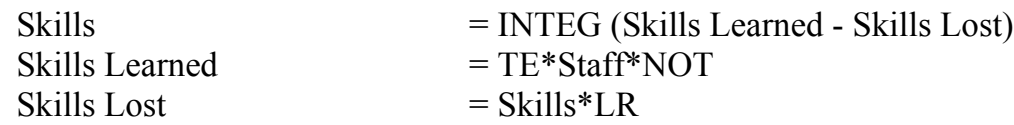

The "Skills Learned" rate of change variable is modelled as the product of the variable "Staff" with a "training efficiency" coefficient (TE) and a coefficient (NOT) indicating "the number of trainings" per time unit. The "Skills Lost" rate of change variable is modelled simply as an exponential decay mechanism with the decay rate (LR) per time unit.

Dynamics of the state variable "Customer Base":

Customer Base

Customer Won

Customer Lost
$=$ INTEG(Customer Won - Customer Lost)

$=$ IF THEN ELSE $(\mathrm{R}+2>0$, Customer Base* $(\mathrm{R}+2), 0)$

$=$ IF THEN ELSE $(\mathrm{CL}<0,-0.1 *$ Customer Base*CL,0)

The "Customer Won" rate of change variable is modelled as a function of some index measuring ("Recommendations" +2 ) (R) per time unit so that if $\mathrm{R}>0$ then "Customer Won" = "Customer Base" multiplied by "Recommendations" (R) and else zero. The constant value of 2 added to the "Recommendations" accounts for the fact that if "Recommendations" equal zero there is still a flow of customers into the firm's base of customers from other firms. The "Customer Lost" 
rate of change variable is modelled in a similar fashion as a function of some index variable "Customer Loyalty" (CL) per time unit and the mechanism is only active if CL $<0$ where it is given by " $-0.1 *$ Customer Base*CL" that is in fact a positive loss and zero else.

Dynamics of the state variable "Orders in Process":

$\begin{array}{ll}\text { WIP } & =\text { INTEG (Orders-Shipments) } \\ \text { Orders } & =\text { OF*Customer Base } \\ \text { Shipments } & =\text { MIN(WIP,AP*Staff) }\end{array}$

The "Orders" rate of change variable is modelled as the product between the "Order Frequency" (OF) per time unit and the "Customer Base". The "Shipments" rate of change variable is modelled as a minimum function between the variables "Work in Process" (WIP) and a handling capacity constraint given by the product between the "Actual Productivity" (AP) per time unit and the number of employees (Staff).

As for now the model is expressed only in time units, but if coefficients as well as functional relations are put in proper sizes relative to a desired time frame the model can be assigned a calendar time dimension, which we will do as follows.

The coefficients which must have the time dimension given by definition are essentially,

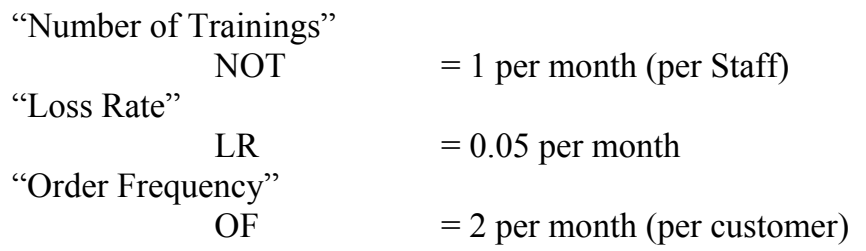

This model is hereby cast in time units equal to months. The actual settings for the variables NOT, LR and OF are clearly in this paper entirely arbitrary and primarily for illustrative purposes, as is the model structure in general. The various functional relations are primarily chosen as simple as possible, just to make a generic point of argument.

Now let us deal with the variables TE, R, CL and AP and the functional assumptions that determine their behaviour

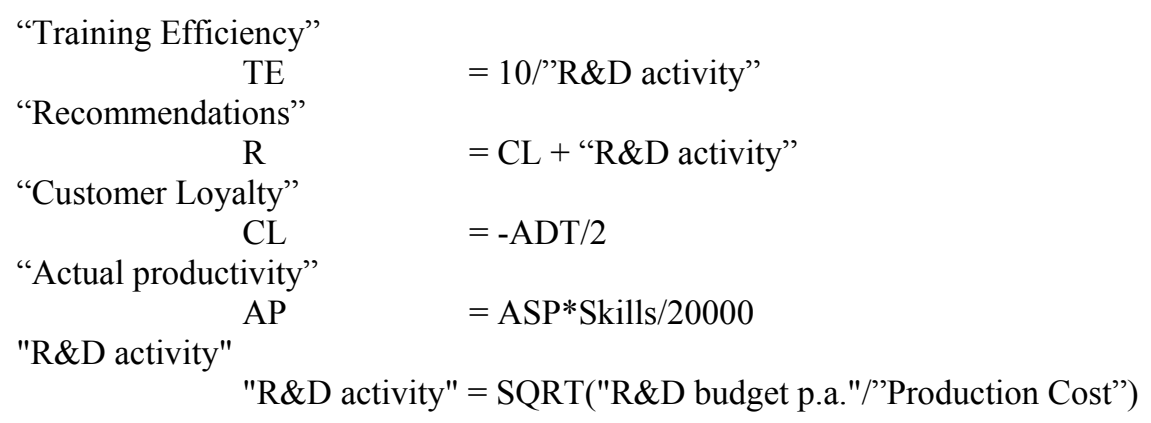

The "R\&D activity" is defined as the square root of the ratio between the per year budget for $R \& D$ purposes and the company's running total operative cost.

The logic of the TE function is that when the "R\&D activity" variable is small (close to zero), it should mean that the relative weight of "R\&D" in the overall business activities is small and the "Training Efficiency" should be higher due to the assumption that training on a more static product portfolio is more efficient. If the "R\&D activity" variable is high, it means that the relative weight of "R\&D" in the overall business activities is more dominant and the "Training Efficiency" is lowered somewhat due to training in relation to a more varying product portfolio. The "Recommendations" variable is also a function of the "R\&D activity" variable which is added 
linearly to a "Customer Loyalty" variable, so both an increased activity in "R\&D activity" as well as an increased "Customer Loyalty" will imply an increase in "Recommendations" and vice versa. "Actual Productivity" (AP) is defined as "Actual Standard Productivity" (ASP) scaled by the expression "Skills/20000". "Actual Standard Productivity" (ASP) is defined as "Standard Productivity" (SP) scaled by the expression 1-("Time Away"*NOT/”Working Days) per Month".

Besides the financial variables which are straightforward in their expressions and interpretations, the last vital model component is the "Actual Delivery Time" (ADT).

ADT $\quad=($ Orders + WIP $) /($ Shipments +1$)$

It is a rough indicator of the actual delivery time and should be interpreted basically as a psychological reaction measure to delivery problems in this model in connection with the "Customer Loyalty" variable.

Finally some constants of the model will be as follows

Table 1

\section{Constants of the model}

\begin{tabular}{lr}
\hline \hline CONSTANTS & Value \\
\hline Capital Employed & $1 \mathrm{e}+007$ \\
Cost per Head & 2 \\
Cost per Training & 10 \\
Material Cost per Unit & 10 \\
Unit Price & 100 \\
Staff & 100 \\
Std. Productivity & 100 \\
Time Away & 1 \\
Working Days per Month & 20 \\
\hline
\end{tabular}

The model operates a couple of performance indicators besides of course "Skills", "Customer Base" and "Work in Process"

\author{
RoCE p.a. \\ Staff Utilization \\ Profit p.a. \\ R\&D activity
}

$$
\begin{aligned}
& =\text { Profit p.a./Capital Employed } \\
& =\text { Shipments/(Actual productivity*staff) } \\
& =\text { SMOOTH(profit, 12) } \\
& =\text { SQRT }(\text { R\&D budget } \text { p.a./Production Cost) }
\end{aligned}
$$

These indicators obviously cover both the financial as well as the non-financial aspects of the overall systems performance as should be the case if we actually want to take a BSC-view on system performance and control.

Before running a couple of illustrative scenarios to unfold some aspects of the actual dynamics of the given BSC model proposed, it is advisable to get the expectations set right as to the dynamic capabilities of the model.

The System Dynamics tool for this operation is the so-called closed loop analysis that aims at the entanglement of the signs between different elements in the model as well as for complete closed loops embedded in the model. Further analysis can be performed to establish the dominant loop structure, which essentially tells us what kind of dynamics the model will produce.

If we analyse the closed loop structure of the model from the respective stand point of the three state variables in turn we get the following statistics

$$
\begin{array}{lll}
\text { - } & \text { Skills } & \rightarrow 10 \text { closed loops } \\
\text { - } & \text { Customer Base } & \rightarrow 19 \text { closed loops }
\end{array}
$$




\section{- $\quad$ Work in Process $\rightarrow 10$ closed loops}

This immediately unveils a complicated dynamic structure of the model that would, if the model was to be used for more than illustrative purposes, require a most complicated dominant closed loop analysis. However we will settle for a more uncomplicated approach namely the loop signs embedded in the model extracted to the BSC figure 2 and shown in figure 4.

\section{Figure 4}

\section{The extracted model of BSC}

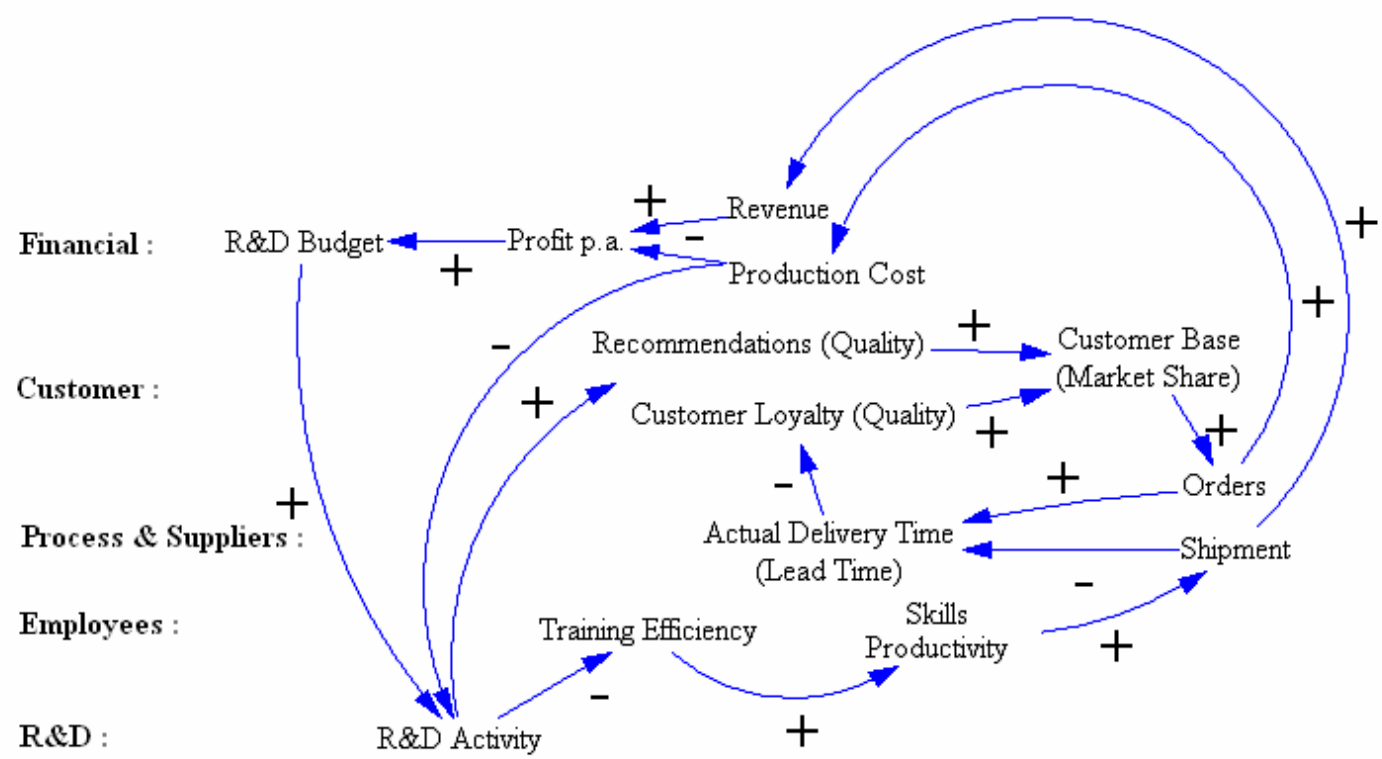

Let us isolate a couple of important closed loops in the structure depicted in figure 4 . In determining the sign that will characterize the full closed loop, the number of negative partial signs has to be summed. If the sum is even, the loop is positive or self - reinforcing; if the sum is odd, then the loop is negative or essentially stabilizing.

(1) Negative (stabilizing) loop structure:

Orders $\rightarrow$ Actual Delivery Time $\rightarrow$ Customer Loyalty $\rightarrow$ Customer Base $\rightarrow$ Orders

(2) Positive (reinforcing) loop structure:

Orders $\rightarrow$ Production Cost $\rightarrow$ R\&D Activity $\rightarrow$ Training Efficiency $\rightarrow$

$\rightarrow$ Skills $\rightarrow$ Shipment $\rightarrow$ Actual Delivery Time $\rightarrow$ Customer Loyalty $\rightarrow$ $\rightarrow$ Customer Base $\rightarrow$ Orders

(3) Positive (reinforcing) loop structure:

$$
\begin{gathered}
\text { Orders } \rightarrow \text { Production Cost } \rightarrow \text { Profit p.a. } \rightarrow \text { R\&D Budget } \rightarrow \text { R\&D Activity } \rightarrow \\
\rightarrow \text { Training Efficiency } \rightarrow \text { Skills } \rightarrow \text { Shipment } \rightarrow \text { Actual Delivery Time } \rightarrow \\
\rightarrow \text { Customer Loyalty } \rightarrow \text { Customer Base } \rightarrow \text { Orders }
\end{gathered}
$$

(4) Negative (stabilizing) loop structure: 
(5) Negative (stabilizing) loop structure:

$$
\begin{gathered}
\text { Orders } \rightarrow \text { Production Cost } \rightarrow \text { R\&D Activity } \rightarrow \text { Recommendations } \rightarrow \\
\rightarrow \text { Customer Base } \rightarrow \text { Orders }
\end{gathered}
$$

$$
\begin{gathered}
\text { Orders } \rightarrow \text { Production Cost } \rightarrow \text { Profit p.a. } \rightarrow \text { R\&D Budget } \rightarrow \text { R\&D Activity } \rightarrow \\
\rightarrow \text { Recommendations } \rightarrow \text { Customer Base } \rightarrow \text { Orders }
\end{gathered}
$$

(6) Negative (stabilizing) loop structure:

$$
\begin{aligned}
\text { Shipment } & \rightarrow \text { Revenue } \rightarrow \text { Profit p.a. } \rightarrow \text { R\&D Budget } \rightarrow \text { R\&D Activity } \rightarrow \\
& \rightarrow \text { Training Efficiency } \rightarrow \text { Skills } \rightarrow \text { Shipment }
\end{aligned}
$$

(7) Negative (stabilizing) loop structure:

$$
\begin{gathered}
\text { Shipment } \rightarrow \text { Actual Delivery Time } \rightarrow \text { Customer Loyalty } \rightarrow \text { Customer Base } \rightarrow \\
\rightarrow \text { Orders } \rightarrow \text { Production Cost } \rightarrow \text { Profit p.a. } \rightarrow \text { R\&D Budget } \rightarrow \text { R\&D Activity } \rightarrow \\
\rightarrow \text { Training Efficiency } \rightarrow \text { Skills } \rightarrow \text { Shipment }
\end{gathered}
$$

(8) Positive (reinforcing) loop structure:

$$
\begin{aligned}
& \text { Shipment } \rightarrow \text { Actual Delivery Time } \rightarrow \text { Customer Loyalty } \rightarrow \text { Customer Base } \rightarrow \\
& \rightarrow \text { Orders } \rightarrow \text { Production Cost } \rightarrow \text { R\&D Activity } \rightarrow \text { Training Efficiency } \rightarrow \text { Skills } \rightarrow \text { Shipment }
\end{aligned}
$$

In this accounting of loops we have 3 positive self-reinforcing loops and 5 negative stabilizing loops. Now care must be observed in seeking to understand such loop information. Positive selfreinforcing loops are not necessarily destabilizing and negative stabilizing loops are not always stabilizing. How can this make sense?

If a positive self-reinforcing loop is all by itself, it will indeed go crazy and result in an exploding time pattern where the variables approach plus or minus infinity. But if a positive selfreinforcing loop is embedded in a system of other positive and/or negative loops, there may be certain interaction in the system that reverses an otherwise unstable development all in all resulting in a controlled outcome. With respect to negative stabilizing loops the dynamic movement towards some fix-point value can be so over-exaggerated that the dynamic path results in oscillations around the fix-point but with ever increasing amplitude.

What has to be expected from actual simulations with the BSC model is consequently somewhat inconclusive given the loop information obtained in loop 1-8. However, the information in loop 1-8 is extremely important when certain behaviour is sought during a simulation session with a System Dynamics model. Anybody with experience in manipulating System Dynamics models in general will know that the abundance of parameters and even more abundant combinations of parameter values almost make a targeted search impossible if no structural knowledge is available - and such information constitutes the information given in loop 1-8.

\section{Model simulation scenarios}

In the following we analyse three simple scenarios or strategies relative to a base run situation, with focus on the dynamic evolvement of the profit according to table 2. 
Table 2

Strategies and scenarios

\begin{tabular}{cl}
\hline Strateqy & \multicolumn{1}{c}{ Relevant variables } \\
\hline We want to "maximize" profit & $\begin{array}{l}\text { Training effort relative to given staff } \\
\text { (NOT increased from 1 to 2) }\end{array}$ \\
We want to "maximize" profit 5 years & $\begin{array}{l}\text { Staff adjustment } \\
\text { ("Staff" increased from 100 to 135) } \\
\text { within 5 years }\end{array}$ \\
$\begin{array}{c}\text { Increased order frequency } \\
\text { ("Order Frequency" increased from 2 to 3) }\end{array}$ \\
within 5 years
\end{tabular}

The base model will be parameterized as described in the documentation given above and the initialization values for the state variables "Skills", "Work in Process" and "Customer Base" will be set to $10,000,1,000$ and 2,000 respectively.

Figure 5

\section{The parameterized BSC model}

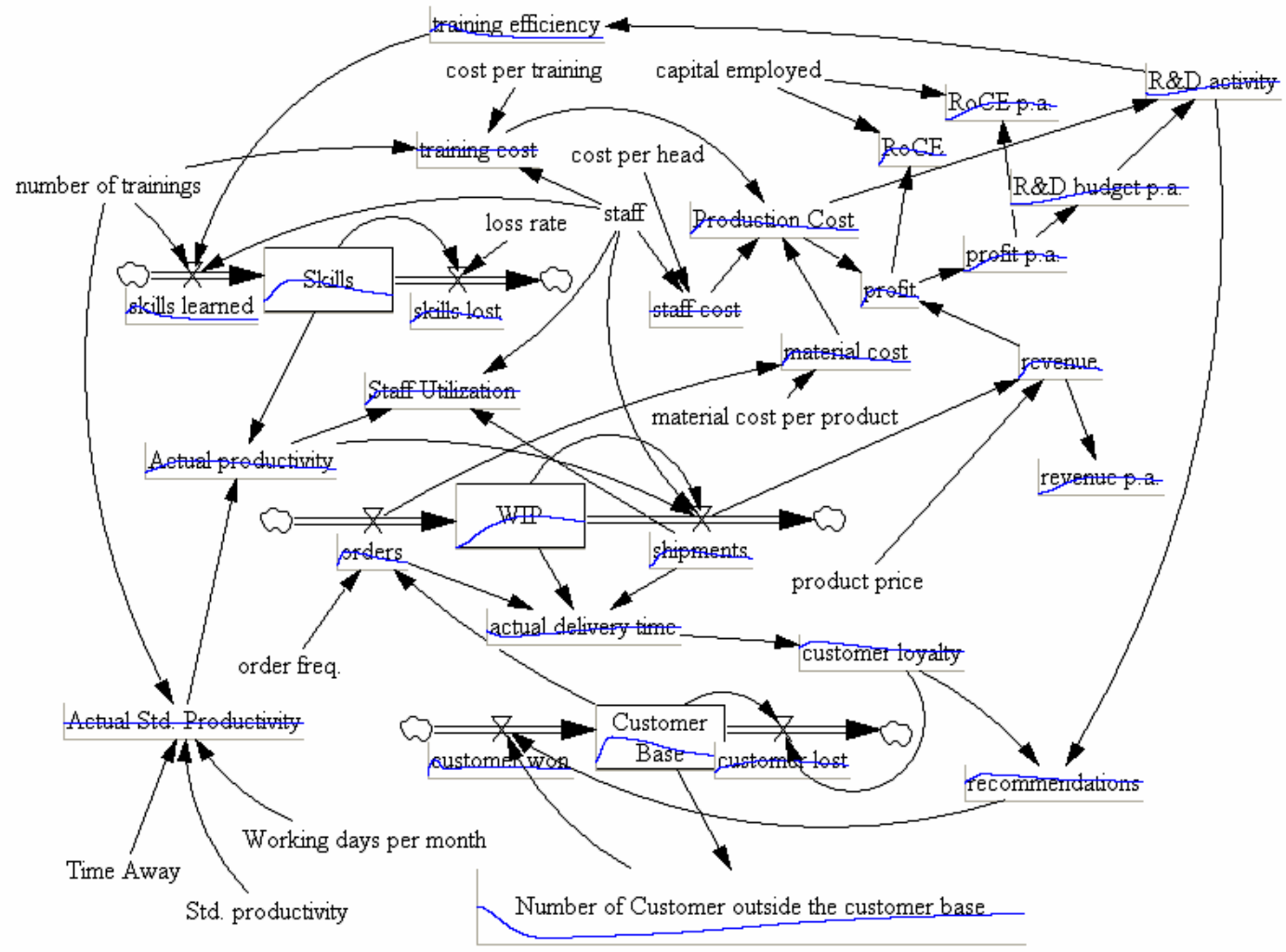

A closer view into the time plot of "Profit p.a." and "Number of Customer outside the Customer Base" alias potential customers will be as follows, shown in figure 6 . 
Figure 6

First scenario: Present situation

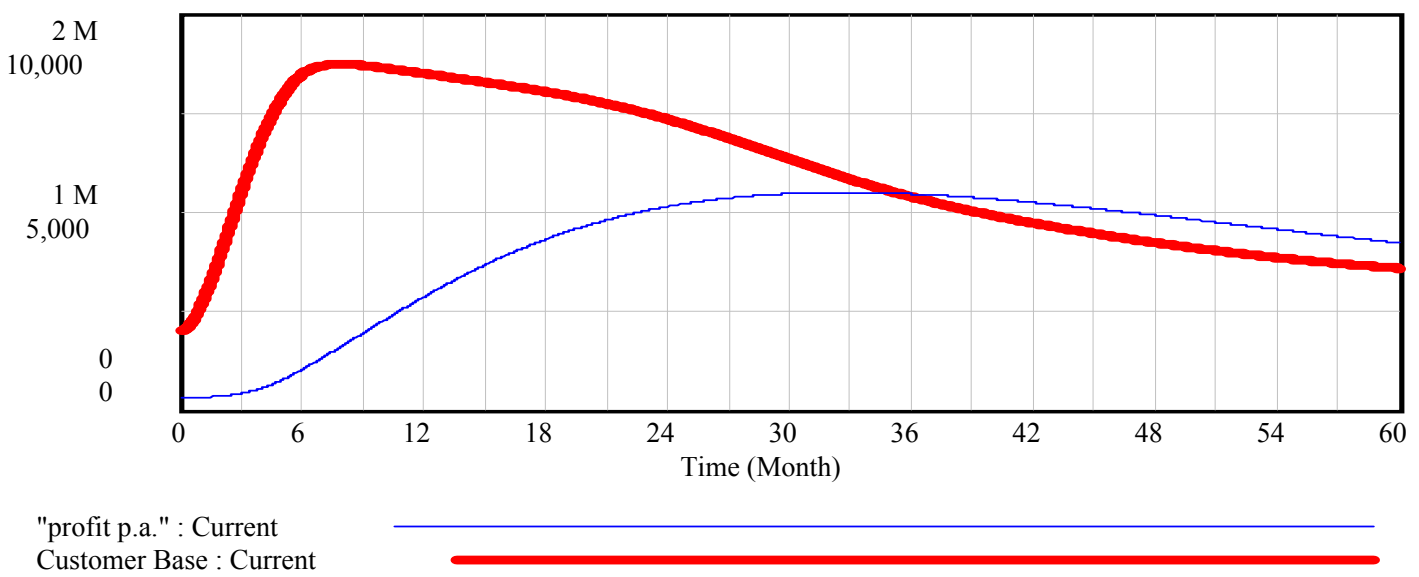

A quick inspection reveals that the company is in trouble. The company looses its customer base already within the first six months and profits start to decline around year 3. This is serious. By the way, the "Staff Utilization" $=100 \%$ almost the entire period, and "RoCE p.a." $=8.4 \%$ at the end of the simulation run with a peak value of $13.19 \%$ one year and four months into the run.

To remedy this unfortunate development we have several options. In this model we can essentially increase the "Number of Trainings" variable or we can hire more "Staff" or we can of course introduce actions with the intention of changing some of the relations in the model. This last option is, however, of a more subtle nature and will not be considered in this paper. The variable "Number of Trainings" will be raised from 1 to 2 in the following experiment.

Figure 7

Second scenario: Number of trainings increased from 1 to 2

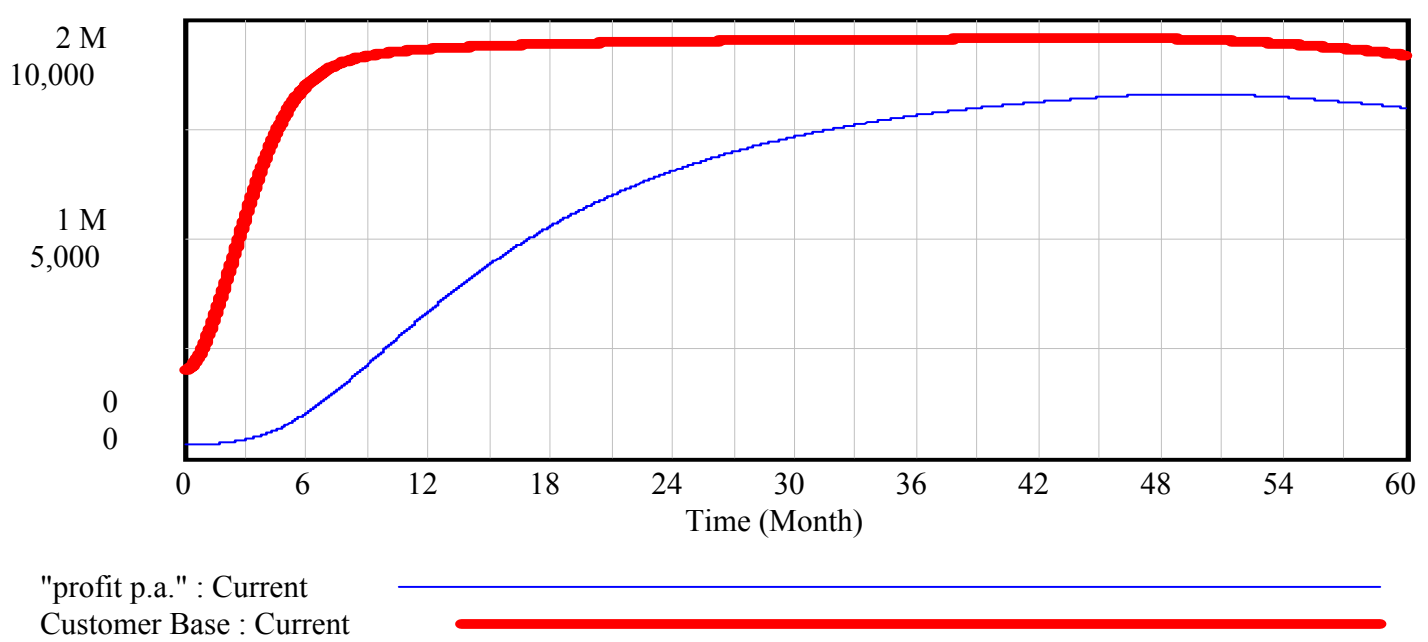

The effect is quite dramatic in that the "Customer Base" now increases sharply to a high level, that seems to be maintained nicely, and the "Profit p.a." reaches a level almost 1.5 the previous 
level from the base run with "Number of Trainings"=1. Also "RoCE p.a." shows great improvement in that it settles at a value close to $16 \%$ at the end of the simulation period.

The "Staff" variable has the potential to remedy on the base run situation too and given the improvements in performance by increasing "Number of Trainings" from 1 to 2 it seems sensible to ask which "Staff" increase will be needed to obtain the same effect as increasing "Number of Trainings" from 1 to 2 ?

The result turns out to be that "Staff" must be increased from 100 to 135 to off-set an increase of "Number of Trainings" from 1 to 2 . These two solutions to the base run problem are identical not only with respect to "Number of Customer outside the Customer Base" but also with respect to the "Profit p.a." as well as the "RoCE p.a." time patterns.

In the base run the "Order Frequency" was set to a value of 2. If we increase this value to 3 we get the following time plot in figure 8 .

Figure 8

Third scenario: Order frequency increased from 2 to 3

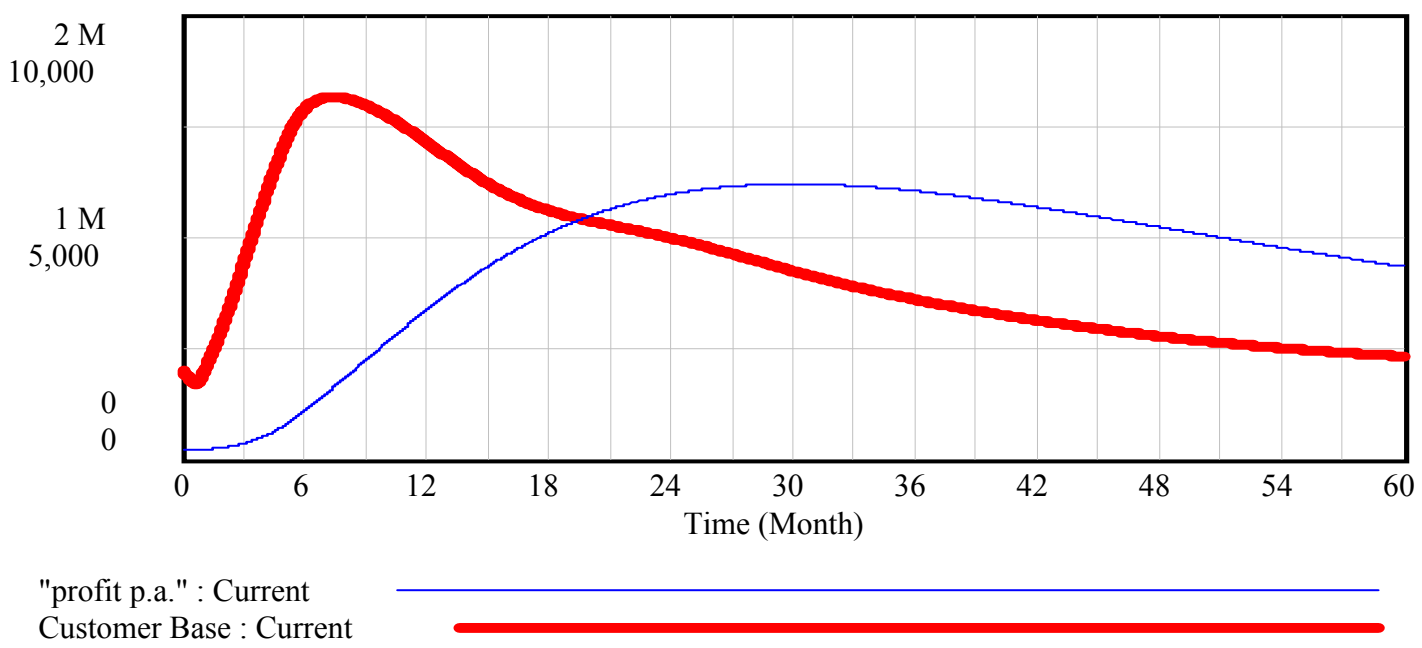

In this case we see that the "Profit p.a." is almost unaltered compared to the base run. But in numbers the "Customer Base" develops to a slightly worse state compared to the base run, where we already had a problem. We are loosing potential customers faster than is comfortable but it does not seem to affect "Profit p.a." - how can this be?

Because we have increased the "Order Frequency", fewer customers take the same amount of business to our company per time unit. So demand may actually not be worsening in comparison to the base run. Anyhow, we do experience an increase in our "Actual Delivery Time" sooner than was the case in the base run, resulting in an earlier loss of customers owing to a precipitated decrease in "Customer Loyalty". Clearly the medicine for this problem is essentially the same as for the base run and one example is given in figure 7.

\section{Summary and conclusion}

One essential aspect of a BSC is the explicit awareness or relation to a given purpose. We have formulated three simple strategies and transformed these into an analytical BSC model based on 'simple' assumed cause-and-effect relationships between various performance measures. Even 
with a relatively simple strategy, the BSC model already becomes relatively complicated as does its dynamic behaviour. As already mentioned, the much discussed cause-and-effect relationships and the time delay or time lag perspective are two important explicit assumptions that eventually have to be considered and evaluated or validated in detail based on real world observations. The base run scenario shows that the company initially is facing a critical situation. The company will essentially loose a large part of its customers within a year and profits will decline severely around year 3 . By the way the staff utilization is $100 \%$ almost the entire period. The first scenario illustrates one of the possibilities available to the company to counteract the unfortunate base run development. One such possibility is to increase the number of periods of training for the employees from one to two, i.e. increase the level of qualifications in general. This simply will raise capacity and the company will be able to take in new customers and thereby raise profit. The second scenario is raising the level of capacity by hiring new personnel and finally, in the third scenario, we try to boost business by increasing the order frequency (heavy advertising etc.). Compared to the base scenario, profit and RoCE will be almost the same as for the base run in this last scenario, so a clear impression emerges that the fundamental problem in our case setup is a plain capacity problem. 


\section{References}

Anthony N. R. \& Govindarajan V. (2004), Management Control Systems, USA, Irwin McGraw-Hill.

Ax, C. and Bjørnenak, T. (2005), "Bundling and Diffusion of Management Accounting Innovations - the Case of the Balanced Scorecard in Sweden", Management Accounting Research, pp. 1-20.

Brinberg, D., McGrath J. E. (1988). Vaility and the Research Process, SAGE Publications, USA.

Bukh, P.N., Frederiksen, J. and Hegaard, M.W. (2000). "Balanced Scorecard på dansk - Ti virksomheders erfaringer", Børsens Forlag, Copenhagen, DK.

Chenhall, R. H., (2003), "Management Control Systems Design Within its Organizational Context: Findings from Contingency-Based Research and Directions for the Future", Accounting, Organizations, and Society, pp. 127168.

Churchman, C. W., Ackhoff, R. L.., Arnoff, E. L. (1957), Introduction to Operations Research, John Wiley \& Sons, Inc. London UK.

Cooper, R. \& Kaplan, R. S. (1999), The Design of Cost Management Systems, Prentice Hall, USA.

Drury, C., 2002. Management \& Cost Accounting, $5^{\text {th }}$ ed., Thomson, UK.

Garrison, R. H. \& Noreen E. W (2000), Managerial Accounting (9 ed.), McGraw Hill USA.

Hahn, D. (1974), Planungs- und Kontrollrechnung als Führungsinstrument, Betriebswirtschaftlicher Verlag Dr. Th. Gabler, Wiesbaden, Germany.

Hillier, F. S., Lieberman, G. J. (1989), Introduction to Operations Research, $4^{\text {th }}$ ed. McGraw-Hill, Int. USA.

Hirsch, M. L. Jr., (2002), Advanced Management Accounting, 2.ed. Thomson, UK

Hoque, Z. and James, W. (2000), "Linking Balanced Scorecard Measures to Size and Market Factors: Impact on Organizational Performance", Journal of Management Accounting Research, pp. 1-17.

Horngren, C. T. (1977), Cost Accounting A Managerial Emphasis, $4^{\text {th }}$ ed., Prentice Hall International Ed. UK.

Horváth, P., Ralf, S. (2004), "Why Budgeting Fails: One Management System is not enough”, Harvard Business Report, September- October.

Ittner, C. D., Larcker, D. F. 2001, “Assessing Empirical Research in Managerial Accounting: A Value-Based Management Perspective", Journal of Accounting and Economics, pp. 349 - 410.

Ittner, C. D., Larcker, D. F. (1998), "Innovation in Performance Measurement: Trends and Research Implications", Journal of Management Accounting Research, pp. 205 - 238.

Johansson, S.-E., Östman, L. (1995), Accounting Theory, Integrating Behaviour and Measurement, Pitman Publishing, UK.

Johnson, H. T., Kaplan, R.S. (1987), Relevant Lost: The Rise and Fal of Management Accounting, Cambridge, MA, Harvard Business School Press.

Kaplan, R. S. (1982), Advanced Management Accounting, Prentice Hall, USA.

Kaplan, R.S. (1998), "Innovation Action Research: Creating New Management Theory and Practice”, Journal of Management Accounting Research, No. 1, pp. 89-118.

Kaplan, R. S. and Atkinson A. A., (1998), Advanced Management Accounting, USA: Prentice Hall International.

Kaplan, R. S. and Norton, D. P. (2004), Strategy Maps. Boston, Harvard Business School Press.

Kaplan, R. S. and Norton, D. P. (2001a), "Transforming the Balanced Scorecard from Performance Measurement to Strategic Management: Part 1", Accounting Horizons, March, pp. 87-104.

Kaplan, R. S. and Norton, D.P. (2001b), “Transforming the Balanced Scorecard from Performance Measurement to Strategic Management: Part 2", Accounting Horizons, June, pp. 147-160.

Kaplan, R. S., and Norton, D. P. (2001c), The Strategy-Focused Organization - How Balanced Scorecard Companies Thrive in the New Business Environment, Harvard Business School Press, USA.

Kaplan, R.S. and Norton, D.P. (1997), “Why does Business Need a Balanced Scorecard?”, Journal of Cost Management, No. 3, pp. 5-10.

Kaplan, R. S., and Norton, D. P. (1996a), "Linking the Balanced Scorecard to Strategy", California Management Review, No. 1, pp. 53-77.

Kaplan, R.S. and Norton, D.P. (1996b), The Balanced Scorecard - Translating Strategy into Action, Harvard Business School Press, Boston, USA.

Kaplan, R. S. and Norton, D. P. (1993), “Putting the Balanced Scorecard to Work”, Harvard Business Review, September-October, pp. 134-142.

Kaplan, R.S. and Norton, D.P. (1992), The Balanced Scorecard - Measures that Drive Performance, Harvard Business Review, No. 1, pp. 71-79.

Kraus, K., and Lind, J. (2002/03), ’Det Balanserade Styrkortets Roll I Företagens Koncernstyrning”, Økonomistyring og Informatik, pp. 663-686.

Laitinen, E. K., (2005), "Micro Economic Analysis of the Balanced Scorecard: A Case of Nokia Corporation", International Journal of Productivity and Performance Management, No. 5/6, pp. 325-339.

Laitinen, E. K., (2004), “Towards a Micro Economic Approach of the Balanced Scorecard”, Managerial Finance, No. 6, pp. 1-27. 
Maisel, L.S. (1992), "Performance measurement: The Balanced Scorecard Approach”, Journal of Cost Management, pp. 47-52.

Malina, M.A. and Selto, F.H. (2001), “Communicating and Controlling Strategy: An Empirical Study of the Effectiveness of the Balanced Scorecard", Journal of Management Accounting Research, pp. 47-90.

Malmi, T. (2001), "Balanced Scorecards in Finish Companies: A Research Note", Management Accounting Research, pp. 207-220.

Nielsen, S., and Sørensen, R. (2004), "Motives, Diffusion and Utilisation of the Balanced Scorecard in Denmark", International Journal of Accounting, Auditing and Performance Evaluation, pp. 103-124.

Nørreklit, H. (2000), "The Balance on The Balanced Scorecard - A Critical Analysis of some of its Assumptions", Management Accounting Research, No. 1, pp. 65-88.

Olve, N.G., Roy, J. and Wetter, M. (1997), Balanced Scorecard I Svensk Praktik, Liber Ekonomi, Sweden.

Porter, M. E. (1985), Competitive Advantage: Creating and Sustaining Superior Performance. New York: The Free Press, USA.

Schöneborn, F. (2003), "Linking the Balanced Scorecard to System Danumics”, Economic System Reports, No. 1. (ISSN 1431-4126), Germany.

Simons, R, (1994), "How top Managers use Control Systems as Levers of Strategic Renewal, Strategic Management Journal, pp. 169-189.

Solomon, D. (1965), Divisional Performance: Measurement and Control, Homewood, H IL., Dow Jones-Irwin, USA.

Sterman, J.D. (2000), Business Dynamics. System Thinking and Modelling for a Complex World. Boston USA.

Sterman, J. D., Repenning, N. P., Kofman F. (1997), "Unanticipated Side Effects of Successful Quality Programs: Exploring a Paradox of Organizational Improvement", Management Science, April, pp. 503-521.

Töpfer, A., and Lindstädt, Föster, K. (2002), "Balanced ScoreCard: Hoher Nutzen zu langer Einführungszeit", Controlling, Heft 2, pp. 79-83.

Varian, H. R. (1997), "How to Build an Economic Model in Your Spare Time”, The American Economist, No. 2, pp. 3-10.

\footnotetext{
${ }^{I}$ The authors also wish to thank MBA-students Nicholas Dalgas Fritsche, and Jesper Johnsen Steen, The Aarhus School of Business, for their help in developing an earlier model in excel of the model.
} 


\section{MODEL APPENDIX}

ADT
WIP
AP
ASP
SP
TA
NOT
WDPM
CE
CPH
CPT
CL
R
LR
MC
MCPP
OF
SC
TC
TE
PC
NCOCB

$=$ Actual Delivery Time

$=$ Work in Process

$=$ Actual productivity

$=$ Actual Std. Productivity

$=$ Std. Productivity

$=$ Time Away

$=$ Number of Trainings

$=$ Working Days per Month

$=$ Capital Employed

$=$ Cost per Head

$=$ Cost per Training

$=$ Customer Loyalty

$=$ Recommendations

$=$ Loss Rate

$=$ Material Cost

$=$ Material Cost Per Product

$=$ Order Freq.

$=$ Staff Cost

$=$ Training Cost

$=$ Training Efficiency

$=$ Production Cost

$=$ Number of Customer outside the customer base
(01)
ADT
$=($ Orders $+\mathrm{WIP}) /($ Shipments +1$)$
(02)
ADT
$=$ ASP $*$ Skills $/ 20000$
ASP
$=\mathrm{SP} *(1-(\mathrm{TA} * \mathrm{NOT} / \mathrm{WDPM}))$
(04)
(05)
CE
$=1 \mathrm{e}+007$
$\mathrm{CPH}$
$=2$
CPT
$=10$

Customer Base $=$ INTEG(Customer Won-Customer Lost,2000)

Customer Lost $=$ IF THEN ELSE $(\mathrm{CL}<0,-0.1 *$ Customer Base*CL,0)

CL $=-\mathrm{ADT}$

Customer Won $=$ IF THEN ELSE $(\mathrm{R}+2>0, \mathrm{NCOCB} *(\mathrm{R}+2), 0)$

FINAL TIME

$=60$

INITIAL TIME $=0$

Loss Rate

$=0.05$

$\mathrm{MC}$

$\mathrm{MCPP}$

$\mathrm{NCOCB}$

NOT

$\mathrm{OF}$

Orders

WIP

Product Price

$$
\begin{aligned}
& =\mathrm{MCPP} * \text { Orders } \\
& =10
\end{aligned}
$$

$=\operatorname{MAX}(10000-$ Customer Base, 0$)$

$=1$

$=2$

Production Cost $=\mathrm{MC}+\mathrm{SC}+\mathrm{TC}$

Profit

Profit p.a.

$=\mathrm{OF}^{*}$ Customer Base

R\&D activity

R\&D budget p.a.

$\mathrm{R}$

Revenue

Revenue p.a.

RoCE

$=$ INTEG(DELAY1(Orders,2,1000)-Shipments,1000)

RoCE p.a.

SAVEPER

$=100$

Shipments

$=$ Revenue-MC-SC-TC

$=$ SMOOTHI(profit, 12,1000)

$=\mathrm{R} \& \mathrm{D}$ budget p.a./PC

$=$ Profit p.a. $/ 5$

$=($ Product Price $) *$ Shipments

$=\mathrm{SMOOTH}($ Revenue, 12$)$

$=$ Profit p.a. $/ \mathrm{CE}$

$=1$

$=\mathrm{MIN}(\mathrm{WIP}, \mathrm{AP} *$ staff $)$ 


\begin{tabular}{lll}
\hline$(34)$ & Skills & $=$ INTEG(skills learned-skills lost,10000) \\
$(35)$ & Skills Learned & $=$ TE*Staff*NOT \\
$(36)$ & Skills Lost & $=$ Skills*LR \\
$(37)$ & Staff & $=$ CPH*Staff \\
$(38)$ & SC & $=100$ \\
$(39)$ & Staff Utilization= Shipments/(AP*Staff) \\
$(40)$ & SP & $=1$ \\
$(41)$ & TA & $=0.0078125$ \\
$(42)$ & TIME STEP & $=$ CPT*NOT*Staff \\
$(43)$ & TC & $=10 / " R \& D$ activity" \\
$(44)$ & TE & $=20$ \\
$(45)$ & WDPM &
\end{tabular}




\section{Working Papers from Management Accounting Research Group}

M-2006-04 Steen Nielsen \& Erland Hejn Nielsen: System Dynamic Modelling for a Balanced Scorecard: With a Special Emphasis on Skills, Customer Base, and WIP.

M-2006-03 Iens Christian Pontoppidan: Økonomistyring af værdi - set i et værdibaseret ledelsesperspektiv.

M-2006-02 Iens Christian Pontoppidan: Risiko og værdibaseret ledelse - set i et økonomistyringsperspektiv.

M-2006-01 Morten Jakobsen: A survey of trust, control and information in networks.

M-2005-07 Pall Rikhardsson \& Pernille Kræmmergaard: Identifying the effects of Enterprise System implementation and use: Examples from Denmark.

M-2005-06 Pall Rikhardsson: Accounting for Health and Safety costs: Review and comparison of selected methods.

M-2005-05 Pall Rikhardsson, Carsten Rohde \& Anders Rom: Exploring Enterprise Systems and Management Control in the Information Society: Developing a Conceptual Framework.

M-2005-04 Jesper Thyssen, Poul Israelsen \& Brian Jørgensen: Activity Based Costing as a method for assessing the economics of modularization - a case study and beyond.

M-2005-03 Christian Nielsen: Modelling transparency: A research note on accepting a new paradigm in business reporting.

M-2005-02 Pall Rikhardsson \& Claus Holm: Do as you say - Say as you do: Measuring the actual use of environmental information in investment decisions.

M-2005-01 Christian Nielsen: Rapporteringskløften: En empirisk undersøgelse af forskellen imellem virksomheders og kapitalmarkedets prioritering af supplerende informationer.

M-2004-03 Christian Nielsen: Through the eyes of analysts: a content analysis of analyst report narratives.

M-2004-02 Christian Nielsen: The supply of new reporting - plethora or pertinent.

M-2004-01 Christian Nielsen: Business reporting: how transparency becomes a justification mechanism. 
ISBN 87-7882-131-2

Department of Business Studies

Aarhus School of Business

Fuglesangs Allé 4

DK-8210 Aarhus V - Denmark

Tel. +4589486688

Fax +4586150188

www.asb.dk 